\title{
Effect of Weight and Cell Size on Hormone-Induced Lipolysis in New Zealand Obese Mice and American Obese Hyperglycemic Mice*
}

\author{
L. Herberg, F.A. Grims and Ch. Hesse-Wortmann
}

Diabetes-Forschungsinstitut und 2. Medizinische Klinik, Universität Düsseldorf, Germany

Summary. In NZO mice fat cell size is strongly correlated to increasing body weight; FFA and glycerol release from adipose tissue under basal conditions and after stimulation with norepinephrine, ACTH, DB-cyclic AMP and theophylline increase with body weight and fat cell size. Normal weight NZO mice and lean littermates of $o b o b$ mice respond similarly to lipolytic agents. - In $o b o b$ mice cell size and body weight are correlated until a body weight of about $60 \mathrm{~g}$ is reached. Older $a b o b$ mice show a decrease in cell size with increasing body weight. There is no correlation between stimulated lipolysis and fat cell size. In these animals an inverse relationship between serum insulin and stimulated lipolysis in adipose tissue was observed. - It is concluded that NZO mice exhibit a type of hypertrophic obesity and obob mice a type of hyperplastic obesity, which may be differentiated by fat cell morphology and the sensitivity of adipose tissue to lipolytic agents.

Effet du poids et du volume des cellules adipeuses sur la lipolyse après stimulation hormonale des souris $N Z O$ et obob

Résumé. Chez la souris NZO, il existe une étroite corrélation entre la dimension de la cellule adipeuse et l'aug. mentation du poids corporel. Chez ces animaux, la libération des $A G L$ et du glycérol à partir du tissu adipeux augmente en fonction du poids et de la dimension des cellules adipeuses, que ce soit dans les conditions de base ou après stimulation par la noradrénaline, l'ACTH, le DB-AMP cyclique et la théophylline. La réponse aux agents lipolytiques est la même chez la souris NZO normopondérale et les souris normales provenant de la même nichée que les souris obob. Chez ces dernières, la dimension de la cellule adipeuse et le poids corporel sont en corrélation jusqu'à un poids corporel d'environ $60 \mathrm{~g}$. Chez des souris $a b o b$ plus âgées, une diminution de la dimension de la cellule est observée lorsque le poids augmente. Aucune corrélation ne peut être établie entre la stimulation de la lipolyse et la dimension de la cellule adipeuse. Il existe une corrélation inverse entre l'insulinémie et la stimulation de lipolyse dans le tissu adipeux. - Il est conclu de ces expériences que les souris NZO pourraient être atteintes d'un type d'obésité hypertrophique et les souris obob d'un type d'obésité hyperplasique, dont la distinction semble pouvoir se faire par l'examen morphologique de la cellule adipeuse et par la sensibilité du tissu adipeux aux agents lipolytiques.

Einfluß von Körpergewicht und Zellgröße auf die hormoninduzierte Lipolyse des epididymalen Fettgewebes bei NZO- und obob-Mäusen

Zusammenfassung. Bei NZO-Mäusen besteht eine enge Korrelation zwischen Zunahme des Körpergewichtes und Vergrößerung der Einzelfettzelle. Unter Basalbedingungen sowie nach Stimulierung mit Noradrenalin, ACTH, DB-cyclo AMP und Theophyllin nimmt die Freisetzung von Glycerin und freien Fettsäuren aus dem Fettgewebe bei $N Z O$-Mäusen mit steigendem Körpergewicht und Vergrößerung der Fettzelle zu. - Junge, nicht fettsüchtige NZO-Mäuse und nicht fettsüchtige Wurfgeschwister hyperglykämischer $o b o b$-Mäuse reagieren in ähnlicher Weise auf lipolytische Stimuli. - Bei obob-Mäusen besteht zwischen der Fettzellgröße und dem Körpergewicht eine Korrelation, bis die Tiere ein Gewicht von ungefähr $60 \mathrm{~g}$ erreicht haben. Bei älteren obob-Mäusen tritt trotz einer weiteren Zunahme des Körpergewichtes eine Abnahme der Fettzellgröße auf. Es besteht keine Korrelation zwischen stimulierter Lipolyse und Fettzellgröße. Die Höhe des Seruminsulinspiegels und die stimulierte Lipolyse des Fottgewebes verhalten sich bei diesen Tieren umgekehrt proportional. - Es wird geschlossen, daß $N Z O$-Mäuse den Typ einer hypertrophischen Fettsucht und obob-Mäuse den Typ einer hyperplastischen Fettsucht verkörpern, die sich hinsichtlich der Fettzellmorphologie und der Empfindlichkeit des Fettgewebes auf lipolytische Agenzien voneinander unterscheiden.

Key-words: Spontaneous diabetes, mutation obob, NZO mice, diabetes in mice, obesity in mice, hereditary obesity, adipose tissue, lipolysis, lipogenesis, size of fat cells.
Obesity in New Zealand obese mice (NZO) and American obese hyperglycemic mice (obob mice) seems to be due both to increased lipogenesis and decreased lipolysis. Increased lipogenesis has been demonstrated in $a b o b$ mice by an increased conversion of labelled carbohydrates into fatty acids of the liver and carcass [13]. In NZO indirect evidence was derived from decreased oxidation of glucose to $\mathrm{CO}_{2}$ as compared with normal controls [22]. Decreased release of free fatty acids from adipose tissue was found by Marshall and Engel $[16]$ who concluded that $o b o b$ mice during fasting exhibit decreased fat mobilization. However, the

* Supported by grants from the Deutsche Forschungsgemeinschaft, Bad Godesberg, and Landesamt für Forschung des Landes Nordrhein-Westfalen, Germany. release of free fatty acids from adipose tissue of starved NZO mice into the incubation medium is significantly greater than from adipose tissue of fed NZO mice [24].

Differences in adipose tissue lipolysis do not only occur between different strains of mice but also between animals of the same species, of different weight and age. Epinephrine-stimulated lipolysis decreases in $o b o b$ mice with increasing age [16]. The uptake of ${ }^{14} \mathrm{C}$-glucose by epididymal fat pads in $o b o b$ mice also declines with increasing age [11]. Since the differences in the lipolytic activity of adipose tissue during fasting in these two strains of mice suggest different types of metabolic obesity, the present study was carried out to evaluate contribution of weight, cell size and serum insulin to fat mobilization in these animals. 


\section{Materials and Methods}

The following animals were used: Swiss albino mice (Müller, Haan, Germany) New Zealand obese mice (NZO mice) from the strain described by Bielschowsky, M.-F. Bielschowsky [3]. C 57 BI. mice and American obese hyperglycemic mice ( $a b o b$ mice) and their lean littermates obtained from the Jackson Memorial Laboratories, Bar Harbor, Maine, USA. They were maintained as previously described [8], allowed free access to food and tap water. Studies were performed with epididymal adipose tissue. Animals were killed by decapitation and bleeding and sufficient quantities of tissue were obtained for both the metabolic studies and the determination of cell size.

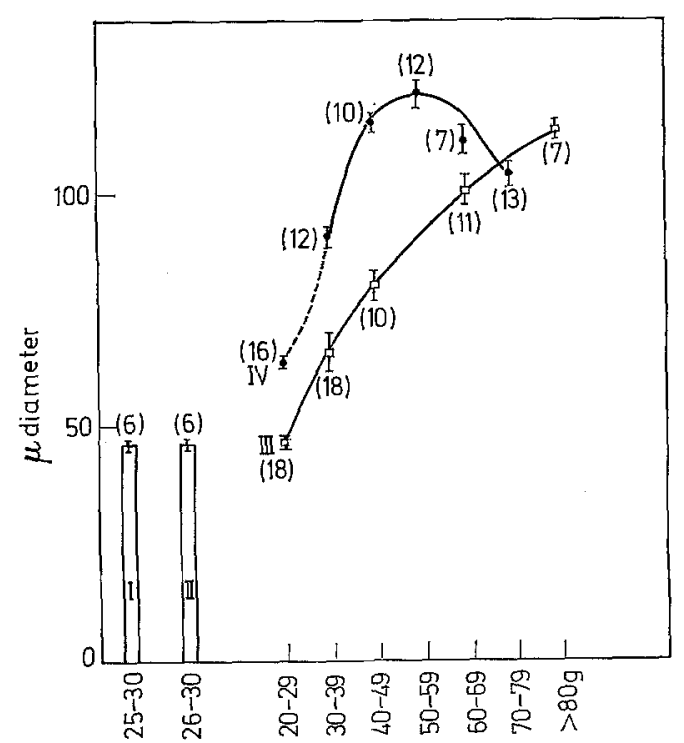

Fig. 1. Body weight and fat cell diameter of Swiss Albino Mice I, C57BL mice II, New Zealand obese mice III, American obese-hyperglycemic mice (obob) IV. The number of animals is indicated in parentheses mean \pm SEM

Incubation of tissue $40-60 \mathrm{mg}$ of epididymal adipose tissue were incubated at $37^{\circ} \mathrm{C}$ in a metabolic shaker oscillating at 80 cycles per minute. Pre-incubation was performed for $30 \mathrm{~min}$ in a modified KrebsRinger bicarbonate buffer containing $4 \mathrm{~g} \%$ human albumin (KRBA) and $5.55 \mathrm{mM}$ glucose. Thereafter the fat pads were transferred to glucose-free KRBA and incubated for $2 \mathrm{~h}$. The reactions were terminated by chilling in ice.

Lipolytic agents. The effect of the following agents

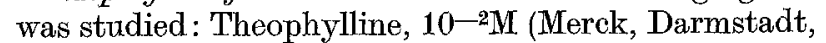
Germany) DB 3,5-cyclic AMP, 10-3M (Boehringer, Mannheim, Germany) Norepinephrine $0.58 \times 10^{-3} \mathrm{M}$ (Hoechst, Frankfurt, Germany) ACTH, $125 \mu \mathrm{U} / \mathrm{ml}$ (Ciba AG, Basel, Switzerland).

Analytical procedures. Free fatty acids (FFA) in buffer were determined by a modification [7] of the method of Itaya and Ui [9]. Glycerol was measured enzymatically according to Kreutz [12] and FFA and glycerol release was related to $\mu$ Mol esterified fatty acids (EFS) of the incubated adipose tissue as determined by the method of Antonis and coworkers [1] and calculated for $10^{5}$ fat cells.

Determination of cell size. Isolated fat cells were liberated from the tissue according to the method of Rodbell [19]. The washed cells were stained with methylene blue, suspended in siliconized counting chambers and measured microscopically.

Calculations. The average lipid content of the single fat cell was calculated according to Faulhaber [4], using the following formula

$$
\begin{aligned}
\mathrm{V} & =\frac{\pi \times d^{3}}{6} \\
G & =\pi \times \frac{d^{3} \times 0.915}{6 \times 10^{6}} \mu \mathrm{g} \text { triglyceride } \\
V & =\quad \text { volume } \\
d & =\quad \text { average fat cell diameter } \\
0.915 & =\quad \text { density of triolein. }
\end{aligned}
$$

From the lipid content of the single fat cell and the EFA content of the tissue, the cell number was calculated.

\section{Results}

Epididymal fat cell diameter and volume in Swiss albino, $C 5^{7} B L$, obob and $N Z O$ mice. When epididymal fat cell diameters of animals of same weight are compared (Fig. 1, Table 1) no difference is observed between Swiss albino mice, NZO mice and $\mathrm{C} 57 \mathrm{BL}$ mice. However, in lean litters of obob mice the diameters are about $40 \%$ greater. In $o b o b$ mice, cell size and volume increase only till the animals have gained

\begin{tabular}{|c|c|c|c|c|}
\hline \multirow{2}{*}{ 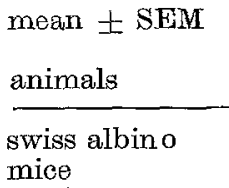 } & \multicolumn{4}{|c|}{$\begin{array}{l}\text { The number of animals is indicated in } \\
\text { parentheses } \\
\text { body weight diameter volume }\end{array}$} \\
\hline & $25-30$ & (6) & $45.7 \pm 1$ & $182 \pm 0.002$ \\
\hline C57BL mice & & $\begin{array}{l}(6) \\
(16)\end{array}$ & & \\
\hline & $30-$ & (12) & & 0.015 \\
\hline glycemic & & (16) & & 2837 \\
\hline & & & & \\
\hline & & (7) & & 2542 \\
\hline$*=$ lean & $70-79$ & (13) & $102.6 \pm 3$ & $2062 \pm 0$ \\
\hline \multicolumn{5}{|l|}{ littermates } \\
\hline & $20-$ & & & .002 \\
\hline \multirow[t]{4}{*}{ obese mice } & & (18) & & $534 \div 0.002$ \\
\hline & & (10) & & $956 \pm 0.052$ \\
\hline & & & & \\
\hline & & & & \\
\hline
\end{tabular}
an average weight of $\mathbf{5 5} \mathrm{g}$ whereafter, in spite of a

Table 1. Body weight (g), diameter ( $\mu$ ) and volume $\left(\times 1000 \mu^{3}\right)$ of fat cells in epididymal adipose tissue in four types of mice

further increment in weight, the cell diameter decreases. On the other hand, in NZO mice a strong correlation exists between increasing body weight and cell size. 
Spontaneous lipolysis in obob and NZO mice. The difference between the two strains of obese hypergly. cemic mice becomes more evident when spontaneous lipolysis is compared (Table 2, Fig. 2). Incubation of fat pad specimens results in a free fatty acid release which markedly increases with body weight in both strains. In $a b o b$ mice an increased glycerol release is

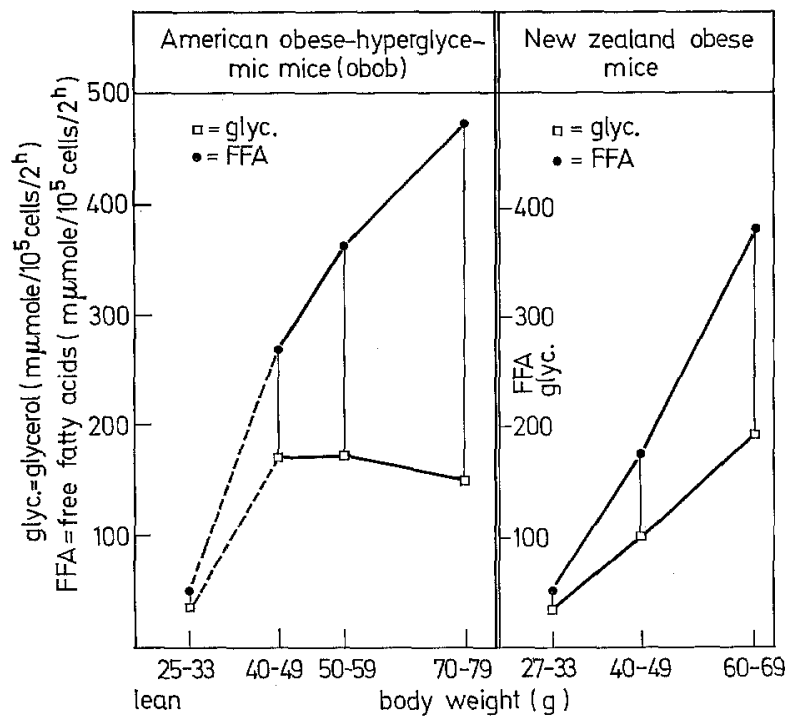

Fig. 2. Spontaneous lipolysis with contribution to body weight in American obese-hyperglycemic mice (obob) and New Zealand obese mice
NZO mice. In lean animals of the three strains studied (Fig. 3) the addition of lipolytic agents results in stimulation of FFA and glycerol release. The response to epinephrine and ACTH in lean littermates and NZO mice is slightly greater than in Swiss albino mice, whereas the stimulation by endogenous and exogenous cyclic AMP is equal in all strains.

FFA and glycerol release in obob mice of different weight and age. In $o b o b$ mice lipolysis is markedly increased by the addition of lipolytic agents when compared to lean litters (Fig. 4). However, the stimulation of lipolysis is age-dependent. The greatest release of FFA is seen in mice weighing $40-49$ or $70-79 \mathrm{~g}$. Adipose tissue of $o b o b$ mice weighing $50-59 \mathrm{~g}$ responds to lipolytic stimulation to a lesser extent. It may be noted that in this age group we found the largest fat cell diameters and divergent reactions to glucose load as shown before. Glycerol release is independent of age.

Stimulated FFA and glycerol release in NZO mice of different weight and age. Both basal and stimulated lipolysis of adipose tissue of NZO mice increases with increasing body weight (Fig. 5). The effect of DB 3,5cyclic AMP, norepinephrine and ACTH is similar. However, theophylline exerts no significant lipolytic effect.

\section{Discussion}

It seems to be a trend of recent research in obesity to consider that even non-endocrine, so-called simple obesity is not a single entity but includes at least two

Table 2. Spontaneous release of free fatty acids (FFA) and glycerol (glyc) in swiss albino mice $=s a$, american obese-hyperglycemic mice $=o b o b$, New Zealand obese mice with contribution to increasing body weight

\begin{tabular}{|c|c|c|c|c|c|}
\hline animals & $\begin{array}{l}\text { body weight } \\
\text { (g) }\end{array}$ & $\begin{array}{l}\text { fat cell dia- } \\
\text { meter }(\mu)\end{array}$ & $\begin{array}{l}\text { FFA } \\
\text { mumole } / 10 \text { cells }\end{array}$ & $\begin{array}{l}\text { glye } \\
\text { h }\end{array}$ & FFA/glye \\
\hline $\begin{array}{l}\text { sa } \\
o b o b \\
\text { *lean lit- } \\
\text { termates }\end{array}$ & $\begin{array}{l}25-30 \\
25-33^{*} \\
40-49 \\
50-59 \\
70-79\end{array}$ & $\begin{array}{r}45.7 \pm 1 \quad(6) \\
72.4 \pm 2(12) \\
114,1 \pm 2(16) \\
120.7 \pm 3(12) \\
102.6 \pm 3(13)\end{array}$ & $\begin{array}{c}35.8 \pm 5.6(6) \\
51.4 \pm 7.3(8) \\
270.8 \pm 46.2(6) \\
363.2 \pm 46.3(6) \\
476.3 \pm 40.0(6)\end{array}$ & $\begin{array}{r}18.0 \pm 1.6(6) \\
35.9 \pm 2.9(8) \\
172.3 \pm 19.0(6) \\
173.8 \pm 29.9(6) \\
153.3 \pm 12.1(6)\end{array}$ & $\begin{array}{l}2.0 \\
1.4 \\
1.5 \\
2.1 \\
3.1\end{array}$ \\
\hline $\mathrm{NZO}$ & $\begin{array}{l}27-33 \\
40-49 \\
60-69\end{array}$ & $\begin{array}{l}54.2 \pm 2(15) \\
79.4 \pm 3(10) \\
99.0 \pm 3(11)\end{array}$ & $\begin{array}{r}52.8 \pm 7.5(6) \\
176.7 \pm 11.8(9) \\
382.0 \pm 52.0(6)\end{array}$ & $\begin{array}{cc}34.7 \pm 68 & (6) \\
102.4 \pm 141 & (8) \\
193.2 \pm 118 & (6)\end{array}$ & $\begin{array}{l}1.5 \\
1.7 \\
1.4\end{array}$ \\
\hline
\end{tabular}

mean $\pm \mathrm{SEM}$

The number of animals is indicated in parentheses

measured in fat pads of animals weighing $40-59 \mathrm{~g}$ and declines with increasing body weight. Consequently the ratio FFA/glycerol release increases in $o b o b$ mice and remains nearly unchanged in NZO mice. In lean siblings and in NZO mice of the same weight the release of FFA and glycerol per fat cell is equal whereas the cell diameters are different. It is insignificantly greater than in adipose tissue of Swiss albino mice (Table 2).

Stimulated FFA and glycerol release in Swiss albino mice, lean littermates of obob mice and normal weight different types which can be characterized by differences in adipose tissue morphology. In man Preiss and coworkers [17] showed that in some patients the increment in adipose tissue mass is due to increasing cell size while in other forms of obesity there must be an additional increment in cell number. Salans and coworkers [20] and Jahnke and coworkers [10] came to the same conclusions in man and Hellman [5] proposed different types of similar characteristics in obese- hyperglycemic mice. As we have shown in NZO the size of the fat cell grows continously and in proportion to 
body weight. Since the volume of the cell is increased 17-fold, it can be calculated that in these animals the increase in body weight which is about $50 \mathrm{~g}$, may be completely due to this process. The type of obesity in NZO mice may therefore be called hypertrophic obesity. eous, the type of obesity in $o b o b$ mice may therefore be called hyperplastic obesity.

It is of interest that these two types of obesity are associated with differences in adipose tissue metabolism. The hypertrophic form of obesity in NZO mice shows a nearly linear increment in spontaneous and stimulat-

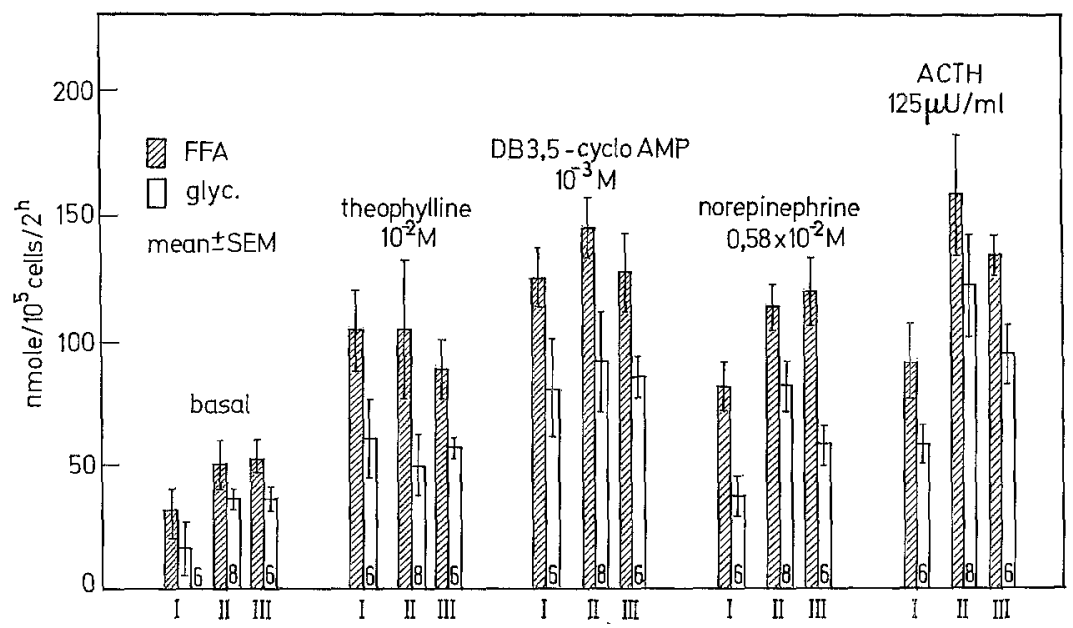

Fig. 3. Effect of theophylline, 3,5 DB-cyclo AMP, norepinephrine and ACTHI on release of free fatty acids (FFA) and glycerol (glye) by adipose tissue in vitro

$\mathrm{I}=$ Swiss albino mice $(25-30 \mathrm{~g})$

II $=$ American obese-hyperglycemic mice (lean; $25-33 \mathrm{~g}$ )

III $=$ New Zealand obese mice $(27-33 \mathrm{~g})$

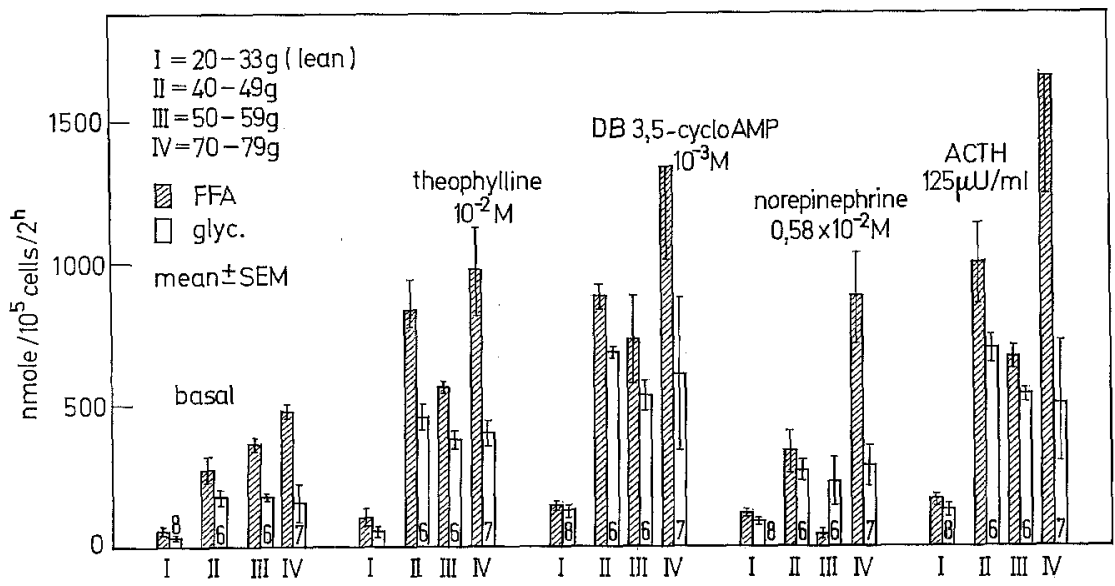

Fig. 4. Effect of theophylline, 3,5 DB-cyclo AMP, norepinephrine and ACTH on release of free fatty acids (FFA) and glycerol (glye) by adipose tissue in vitro in American obese-hyperglycemic mice (obob)

By contrast in $o b o b$ mice fat cell size and body weight are only correlated during the first months of age When the maximal fat cell size is reached, the diameter of the fat cells in subcutaneous and perirenal adipose tissue remains constant (unpublished observation) in spite of an increase in weight and total body lipid content [2]. Since epididymal fat cells decrease not only in size but also in number $[5,6]$ this can only be understood if the number of cells in other locations increases. As the main deposition of fat is subcutan- ed lipolysis with increasing fat cell volumes. It is noteworthy that the ratio FFA/glycerol release is not dependent on fat cell diameter and/or the nature of stimulation. It cannot be decided whether the sensitivity of lipolysis is a function of cell size, since other factors, due to changes of the hormonal and metabolic situation in the organism of the obese may also play a role in lipid mobilization. On the other hand, basal and stimulated lipolysis in $o b o b$ mice does not exhibit such a correlation with either age or weight. Spontaneous 
FFA release also increases but glycerol release remains unchanged with increasing weight. According to the current hypotheses decreased re-esterification may be they were not observed when fat mobilization was related to nitrogen, due to the relatively higher nitrogen content of adipose tissue of $a b o b$ mice $[14,16]$.

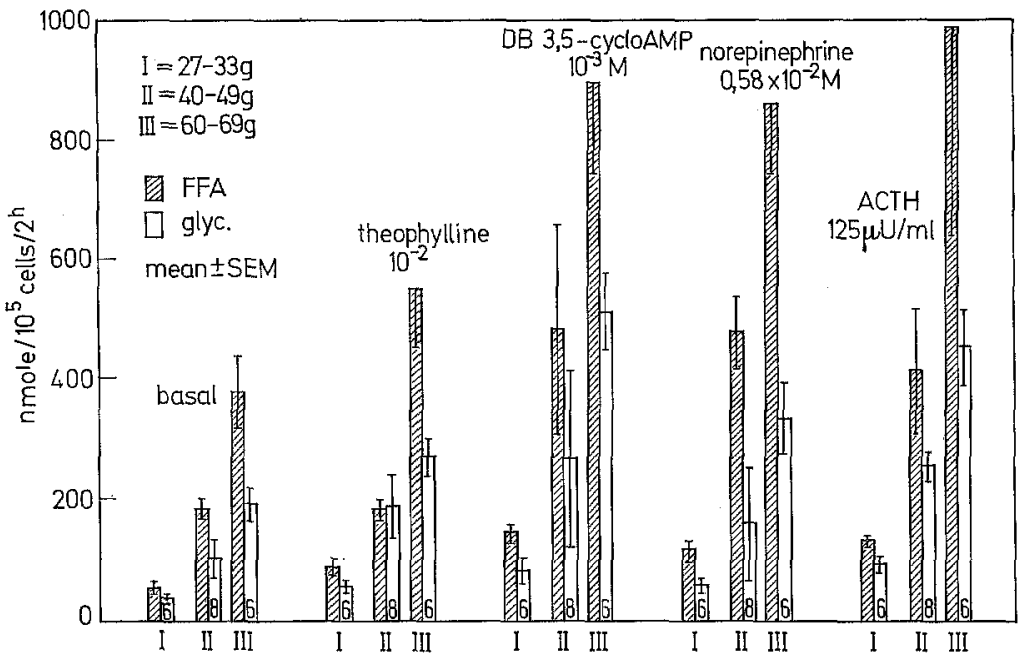

Fig. 5. Effect of theophylline, 3,5 DBcyclo AMP, norepinephrine and ACTH on release of free fatty acids (FFA) and glycerol (glyc) by adipose tissue in vitro in New Zealand obese mice

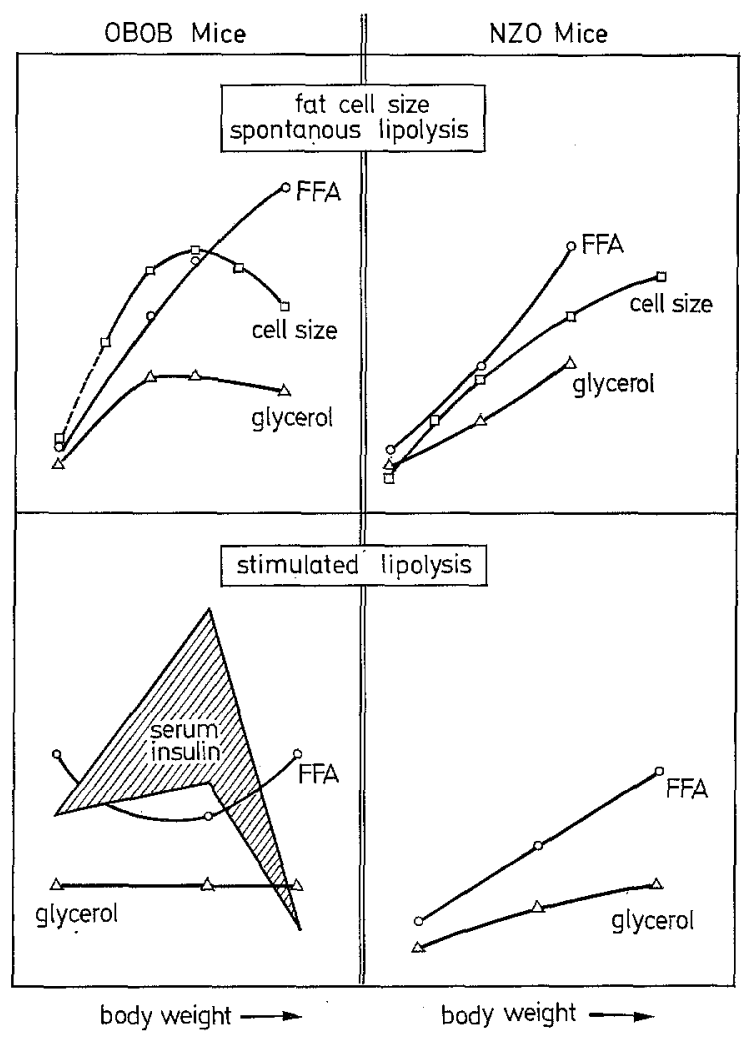

Fig. 6. Epididymal fat cell size, spontaneous lipolysis and stimulated lipolysis with contribution to body weight in $o b o b$ mice and NZO mice

postulated. However, it is also possible that an increased activity in glycerolkinase [23] may result in more pronounced intracellular re-utilization of glycerol. Similar results have been obtained when the basal FFA release was related to wet weight [25] but
In contrast to $\mathrm{NZO}$ mice stimulated lipolysis in obob mice is not correlated to cell size. The greatest lipolytic response is found in fat cells of submaximal diameter, whereas fat cells with maximal size exhibit the smallest response.

Since the changes in lipolytic response were observed after addition of norepinephrine or ACTH as well as theophylline or DB 3,5-cyclie AMP it may be concluded that the decreased lipolysis in animals weighing $50-59 \mathrm{~g}$ is due neither to a disturbed reaction of a first messenger with the reactor side [18] at the cell membrane nor to endogenous cyclic-AMP production but rather to a defect in the mechanism of activation of the inactive prolipase. In agreement with this, Lochaya and coworkers [15] observed a decreased lipase activity in adipose tissue in about 4 months old mice.

From the observation in $o b o b$ mice it may thus be concluded, that factors other than cell size are responsible for the changing sensitivity to lipolytic agents. It seems noteworthy that the lipolytic response decreases simultaneously with fat cell proliferation. This occurs at the time when, for a short period, excessively high serum insulin levels can be observed. Although insulin resistance of glucose metabolism has been demonstrated in $o b o b$ mice [21] this need not implicate a resistance of adipose tissue in lipolysis or possibly cell proliferation and it may be speculated that insulin is of importance to both phenomena.

\section{References}

1. Antonis, A., Platt, A.S., Thorp, J.M.: Automated method for the colorimetric determination of plasma free fatty acids. J. Lip. Res. 6, 301-306 (1965).

2. Bates, M.W., Nauss, S.F., Hagman, N.C., Mayer, J.: Fat metabolism in three forms of experimental obes- 
ity. I. Body composition. Amer. J. Physiol. 180, $301-$ 303 (1955).

3. Bielschwosky, M., Bielschowsky, F.: The New Zealand strain of obese mice. Their response to stilboestrol and to insulin. Aust. J. exp. Biol. med. Sci. 34, $181-198$ (1956).

4. Faulhaber, J.D., Petruzzi, E.N., Eble, H., Ditschuneit, H.: In-vitro-Untersuchungen über den Stoffwechsel isolierter menschlicher Fettzellen in Abhängigkeit von der Zellgröße: Die durch Adrenalin induzierte Lipolyse. Hormon- und Stoffwechselforschung 1, $80-86$ (1969).

5. Hellman, B.: Studies in obese-hyperglycemic mice. Ann. N.Y. Acad. Sci. 131, $541-558$ (1965).

6. - Larsson, S., Westman, S.: Mast cell content and fatty acid metabolism in the epididymal fat pad of obese mice. Acta physiol. scand. 58, 255-262 (1963).

7. Herberg, L., Hesse-Wortmann, Ch.: (unpublished).

8. - Major, E., Hennings, U., Grüneklee, D., Freytag, G., Gries, F.A.: Differences in the development of obese-hyperglycemic syndrome in NZO and obob mice. Brook Lodge Workshop (1969).

9. Itaya, K., Ui, M., Colorimetric determinations of free fatty acids in biological fluids. J. Lip. Res. 6, 16-19 $(1965)$.

10. Jahnke, K., Daweke, H., Liebermeister, H., Schilling, W.H., Thamer, G., Preiss, H., Gries, F.A.: Hormonal and metabolic aspects of obesity in humans. Proc. VIth Congress Internat. Diabetes Fed., Stockholm 1967, 533-539. Amsterdam: Excerpta Medica Found. 1969.

11. Jansen, G.R., Zanetti, M.E., Hutchison, C.F.: Studies on lipogenesis in vivo. Fatty acids and cholesterol synthesis in hyperglycemic-obese mice. Biochem. $\mathrm{J}$. 102, 870-877 (1967).

12. Kreutz, F.H.: Enzymatische Glycerinbestimmung. Klin. Wschr. 40, 362-363 (1962).

13. Lamdin, E., Shreeve, W.W., Slavinski, R.H., Oji, N.: Biosynthesis of fatty acids in obese mice in vivo. II. Studies with DL-Malate-2- ${ }^{3} \mathrm{H}-3-{ }^{14} \mathrm{C}$, Succinate-2,3${ }^{3} \mathrm{H}-2,3-{ }^{14} \mathrm{C}$ and DL-Isocitrate-2- ${ }^{3} \mathrm{H}-5,6-{ }^{14} \mathrm{C}$. Biochemistry 8, 3325-3331 (1969).

14. Leboeuf, B., Lochaya, S., Leboeuf, N., Wood, F.C., Jr., Mayer, J., Cahill, G.F., Jr.: Glucose metabolism and mobilization of fatty acids by adipose tissue from obese mice. Amer. J. Physiol. 201, 19-22 (1961).
15. Lochaya, S., Hamilton, J.C., Mayer, J.: Lipase and glycerokinase activities in the adipose tissue of obesehyperglycemic mice. Nature 197, 182 (1963).

16. Marshall, N.B., Engel, F.L.: The influence of epinephrine and fasting on adipose tissue content and release of free fatty acids in obese-hyperglycemic and lean mice. J. Lip. Res. 1, $339-342$ (1960).

17. Preiss, H., Hesse-Wortmann, C., Gries, F.A., Jahnke, K.: Die Größe menschlicher isolierter Fettzellen in Abhängigkeit vom Ernährungszustand. Die Ernährungslehre 69, 827 (1967) (Abstract).

18. Robinson, G.A., Butcher, R.W., Sutherland E.W.: Adenyl cyclase as an adrenergic receptor. Ann. N.Y. Acad. Sci. 139, 703 - 723 (1967).

19. Rodbell, M. : Metabolism of isolated fat cells. I. Effect of hormones on glucose metabolism and lipolysis. J. biol. Chem. 230, $375-380$ (1964).

20. Salans, L. B., Knittle, J. L., Hirsch, J.: The role of adipose cell size and adipose tissue insulin sensitivity in the carbohydrate interolerance of human obesity. J. clin. Invest. 47, 153-165 (1968).

21. Stauffacher, W., Crofford, O.B., Jeanrenaud, B., Renold, A.E.: Comparative studies of muscle and adipose tissue metabolism in lean and obese mice. Ann. N.Y. Acad. Sci. 131, 528-540 (1965).

22. Subrahmanyam, K.: Metabolism in the New Zealand strain of obese mice. Biochem. J. 76, 548-556 (1960).

23. Treble, D.H., Mayer, J.: Glycerolkinase activity in white adipose tissue of obese-hyperglycemic mice. Nature 200, 363-364 (1963).

24. Westman, S.: In vitro metabolism of epididymal adipose tissue from New Zealand obese-hyperglycemic mice. Utilization of $\mathrm{C}^{\mathbf{1 4}} 1$-Acetate and release of free fatty acids. Metabolism 144, 1027-1033 (1965).

25. - Hellman, B.: Release of free fatty acids from the isolated epididymal fat pad of obese-hyperglycemic mice. Med. exp. 8, 193-199 (1963).

Dr. Dr. L. Herberg

Diabetes-Forschungsinstitut

und 2. Medizinische Klinilk

der Universität Düsseldorf

D-4000 Düsseldorf, Moorenstr. 5 